\title{
Teaching English at Junior High School in Indonesian Rural Area: The Implementation of Scientific Approach
}

\author{
Christi Agustin Malaikosa $^{1 *}$ \\ Lita Liviani Taopan ${ }^{2}$ \\ Universitas Tribuana Kalabahi, \\ Alor, NTT \\ *cmalaikosa@gmail.com
}

Article history: Submitted on $13^{\text {th }}$ October, 2020; Accepted on $21^{\text {th }}$ December 2020; Published on 31 th December 2020

\begin{abstract}
The creation of the curriculum aims to improve the quality of education in the country. It is also happening in Indonesia, where the curriculum is always created in order to improve the quality of education in this country. The purpose of this study was to investigate the implementation of scientific approach on teaching English in Junior High School in Indonesian rural areas context especially in Alor Regency. Qualitative method used on this study on pilot project school of 2013 curriculum. The research subject was the English language teacher who have been teaching using 2013 curriculum. The data then analysed use Analysis Interactive's Miles, Huberman and Saldana model. It can be found that teacher already implemented the scientific steps consist of observing, questioning, collecting data, associating and communicating. On the hand, there were still a lot of problems face by the teacher while applying this method, such as: amount of time spent on the activity, large number of students, limited time allocation given, and also lack of teaching sources.
\end{abstract}

Keywords: English Teaching, Implementation, Scientific Approach, Rural Area

\section{ABSTRAK}

Kurikulum dikembangkan untuk dapat meningkatkan kualitas pendidikan. Begitu pula di Indonesia, dimana kurikulum selalu diperbaiki dengan tujuan untuk meningkatkan mutu dan kualitas pendidikan di Indonesia. Penelitian bertujuan untuk mengetahui penerapan pendekatan saintifik dalam pembelajaran Bahasa Inggris di SMP di daerah perbatasan. Penelitian ini merupakan penelitian kualitatifyang dilaksanakn pada SMP pilot proyek kurikulum 2013. Subjek penelitian adalah guru Babasa Inggris yang selama ini mengajar menggunakan kurikulum 2013. Data yang dipeoleh kemudian dianalisis menggunakan model Analysis Interactive's Miles, Huberman dan Saldana. Hasil 
penelitian menunjukkan bahwa guru sudah melaksanakan langkah-langkah kegiatan saintifik yang terdiri dari kegiatan mengamati, menanya, mengumpulkan data, mengasosiasikan dan mengkomunikasikan. Namun disisi lain masib banyak kendala yang dibadapi guru selama menerapkan metode ini, seperti: banyak waktu yang dihabiskan untuk, tiap kegiatan saintifik, jumlah siswa yang banyak, alokasi waktu yang terbatas serta kurangnya sumber belajar yang ada.

Kata Kunci: Pengajaran Bahasa Inggris, Implementasi, Pendekatan Saintifik, Daerah Perbatasan

\section{INTRODUCTION}

Currently, the Indonesia has implemented a new curriculum, namely the 2013 Curriculum. This curriculum is applied based on reflection and refinement of the previous curriculum implementation. The 2013 curriculum developed to produce productive, creative, innovative, and effective Indonesians through strengthening in attitudes, knowledge, and skills (Kementerian Pendidikan dan Kebudayaan, 2014). This is also emphasized by Mulyasa (2016: 66) that, the 2013 curriculum is a competency-based curriculum that includes knowledge, skills, and attitudes so that the students in the future can have good cognitive, affective, and psychomotor behaviours. Competency concept is implemented to encourage learners in developing personal abilities, professionalism, and get the benefit of all learning experiences obtained in everyday life (Lee et al., 2014;ji, 2017).

Meanwhile, Sundayana,(2015) stated that in the 2013 curriculum, the basic competence are developed based on student needs. Therefore it is expected that by considering the needs of students, the selected competencies will be more relevant. The 2013 curriculum shows an integrated and active learning process can help students develop their skills including thinking skills, knowledge, attitudes, and behaviours. The implementation of learning itself is carried out by referring to the three components of learning, namely preliminary activities, core activities and closing activities.

Furthermore, in this core activity, teachers are asked to apply scientific learning approach. According to Menteri Pendidikan dan Kebudayaan Republik Indonesia, 2013, the scientific approach involves five learning steps that must be carried out in teaching and learning activities. Teachers are expected to apply this approach in learning in order to help students to build their English communicating skill. Scientific learning approach can be applied for the four skills (listening, speaking, reading, and writing) (Zaim, 2017).

Based on the Peraturan Menteri Pendidikan dan Kebudayaan Republik Indonesia Nomor 22 Tahun 2016 Tentang Standar Proses Pendidikan Dasar Dan Menengah, 2016 concerning with the standard process in the learning, three core parts must be carried out as part of the elaboration of the learning implementation plan made by the teacher. The learning activities carried out must reflect the scientific activities (observing, 
questioning, collecting data, associating and communicating) which are the basics of the implementation of the 2013 curriculum. It will enable students to be more innovate, creative, independent, and develop social skills with peers (Madya, 2007). The teacher expected to be able to properly involve all the learning components contained in the 2013 curriculum to achieve the expected learning objectives.

Learning English is carried out so that students are able to improve their competence and language skills in various communication contexts in everyday life. One approach that focuses on increasing the competence of students to use the language they are learning in various communication purposes is text-based teaching. This learning is learning that refers to the function of language and its use, which is a unity of meaning both spoken and written. Thus, genre-based learning is very relevant to be applied (Kemendikbud, 2016). In addition to this, language learning in Junior High School is designed to provide experience for students in using English texts to understand and apply factual, conceptual, and procedural knowledge related to visible phenomena and events, through speaking, listening, reading, and writing in the concrete realm. The use of text also aims to develop the attitudes and character of students so that they implement learning activities in class and in life activities in their social environment, (Peraturan Menteri Pendidikan Dan Kebudayaan Republik Indonesia Nomor 22 Tahun 2016 Tentang Standar Proses Pendidikan Dasar Dan Menengah, 2016).

Based on the explanation above, it can be understood that the learning process plays an important role in achieving the success and competence of students and teachers as educators. The learning process, which is well-organized and involves holistic aspects of learning (affective, cognitive and psychomotor), is expected to provide space for the development of student creativity and critical thinking. On the other hand, in this learning process using scientific approach teachers are able to developing themselves to become role models in critical thinking, be more innovative, have a leadership spirit, communicative and collaborative as part of the characteristics of educators in the 21st century.

Alor Regency is an part of East Nusa Tenggara Province which is included in Outermost, Leading, and Underdeveloped area has implemented this curriculum since 2016. Based on the preliminary interview with the English teachers they thought that 2013 curriculum is very challenging. Teachers have difficulty making plans related to syllabus development and how to adding the Scientifics elements (observing, questioning, trying, reasoning and communication). Beside that teachers still has problems in implementing learning by involving scientific activities because they are not used to using it and also they still have lack of understanding of scientific learning. This problems were also happen in others rural areas of Indonesia which implemented scientific approach in their teaching and learning activity (Azizah, 2015; Sriwahyuni, 2015 \& Jusnita \& Ismail, 2018). 
Based on that, it is important to do in depth research related to find out the implementation of scientific approach on Teaching English at Junior High School in Rural Area of Indonesia especially in Alor Regency.

\section{METHOD}

This research used qualitative descriptive study (Moleong, 2017) and carried out on pilot project Junior High School which implemented 2013 curriculum in Alor, East Nusa Tenggara on teaching and learning English of the Seventh Grade.

The English teacher become the subject of this research. The data collection techniques used in this study were taken from teaching and learning observation in the classroom, which include the pre-liminary activities, core activities and also the final activities of learning; interviewing with the English teacher regarding with the implementation of scientific approach in the 2013 curriculum; and learning administration documents such as syllabus and lesson plans.

The data then analysed using Analysis Interactive's Miles, Huberman and Saldana model (Miles, Mattew B, Huberman, A. Michael, \& Saldana, 2014) consisting of 3 steps. First, data condensation. In this process all the collecting data from the interview, observations, and document analysis then selected again by the writer into appropriate data needed in this case related to scientific approach. The writer used to double-check and compare data obtained during interviews with teacher, data from observations of learning activities in class, and also lesson plan that design by the teacher. The data which is not relevant with the research problem then were omitted. Next, data display. In this step the selected data then presented in a brief and systematic description about the implementation of scientific approach in the form of narrative. It was described based on the interview, observation and document analysis result. The last step was data drawing and verifying conclusions of this research.

\section{FINDING AND DISCUSSION}

There are several stages of activities in the learning process using scientific learning. The stages of this activity are adjusted to the learning implementation plan that has been made by the teacher. In general, this learning stage has been carried out by following the learning process standards that have been stated in the regulations that established in Indonesia. Based on the results of observations in the learning process by the teacher, the steps taken are as follows:

\section{Observing}

In this activity, the teacher first asked students to sit in groups of 5 people and distributed papers containing the dialogue to be read. After that teacher asked students to read to the conversations in the material. Then the 
students listened to the dialogue which had been read by the teacher. The teacher told the students to focus on the material without doing other activities that could distract the students' concentration, then after finishing the students were asked to imitate the conversation that said by teacher aloud. When the teacher heard that there were students who were wrong in pronouncing certain words, teacher immediately gave the correct pronunciation.

Teacher : Yes, enough. "Don't be noisy please!" "Stop talking! Stop talking!". "Pay attention to the piece of paper", pay attention to the dialogue that I shared. "Now listen to me", Cyprian listen to me please. Pay attention to the text. Ok, "pay attention here". "Listen to me, just listen!" Immanuel please look at the textbook I shared. "Just listen", "what is it? Just listen up. Ok, we start now.

Based on the results of observations in learning activities, it can be seen that the teacher has carried out learning activities by asking students to listen and imitate the dialogue that has been given. This observing activity is also carried out with the same activity at the second meeting with material related to describing animals where students are asked to imitate and listen to the text read by the teacher and also at the third meeting about describing objects in the class.

\section{Asking}

In this activity teachers asked the meaning and function of the words "do" and "does" in a conversation given. Teacher then explained the function of "do/does" to students. Teacher provided illustrations of the material so that students can easily understand the concept of using do/does by showing the subject as a reference in using it.

In groups, students are asked to make simple conversations based on examples that have been previously given about their parent's job. Then teacher asked each group to read it and the other group listened to it.

Student 1 : What does your mother do?

Teacher : Once again what does your mother do?"

Student 1 : "What do your mother do?"

Teacher : "What does not what do?"

Next, the teacher told the right form of "do and does" to the students and after that asked them to do a conversation with their partner. 
Teacher : "Now pay attention here!" Earlier, I still got the error "What do your mother do?" The right answer should be "What does your mother do? I'm sure someone knows. I have crossed it out like this (underlined the words "do" and "does"). There must be someone who knows why you have to add this.

The results of observation showed that the teaching materials appropriate with the syllabus given related to the description of animals. The teacher also asked what information students get in the learning or given text. It stimulated the student's curiosity and increase their motivation in learning.

\section{Associating}

In this learning activity (meeting 1) students asked to make a simple dialogue about their parents' work based on the information they had obtained from their group using the correct English. However, in this activity, completing the table has not been implemented by teacher.

Teacher : "You are now in the group but you have to work the individually on your own exercise book. Discuss it in groups then give the answer. The instructions are "make a short dialogue about job and profession." Please write a short dialogue about "job and profession". I give five minutes to fulfil the assignment.

Student : :Mom do we work it alone?

Teacher : "Yes, but the group leaders must be able to guide their friends".

At the second meeting students told to describe the animal by following the description contained in the dialogue. The teacher helped students understand the words so they can arrange it into good sentences. After the students make a short description of the animal. The teacher challenged the student representatives from each group to write their answers on the board.

Meanwhile, at the third meeting, the teacher asked students to be able to collect information about objects in the class and describe them according to the exercises given.

Teacher: Ok, I hope your group can follow first practice. In the first exercise, (the teacher distributes pictures related to the objects around them to each group). Okay for the first exercise, please look at the picture, pay attention to the picture! In your current assignment, please describe the picture based on their function? As in the example, we have read that. The function of the sofa is to sit. The function of the English book is to read and the function 
of the bowl is to put soup. Now please describe the images in your group. Please, time for part 1 is only 5 minutes.

\section{Exploring}

In this activity, students are asked to play roles by following the dialogue that has been given. In the first meeting, 3 pairs of group representatives came in front of the class to have dialogues related to people and jobs. During their dialogue, teacher giving the attention and also correcting their wrong conversations.

Teacher : "Now in groups please try to read it again". Each group leader please guiding your friends to be able to read this dialogue after that you can come in front of the class and read it aloud. Just five minutes. Just five minutes only 5 minutes. Please help friends to be able to read it.

The teacher then allowed the students to be able to study independently in groups while observing if there were any students who had difficulties in learning. When the time limit had fulfil, the teacher asked the students to focus to the instructions explain by the group.

Teacher: "Ok, time is up! Enough already! Enough, it's time to finish now it's time to move forward ". "Who wants to be the first? Who wants to come first? Sagratia's group! "Once again! Once again! Loudly please!

(They read aloud so that other students can listen to them, while they read the teacher keep watch out the pronunciation and vocabulary conveyed by the students).

Teacher: "Ok, thank you very much! Give applause please! " (while clapping). "Next, okay, Dea's group.

On this activity, the teacher established students' errors in pronunciation. It made the teacher paused the conversation and corrected it by giving suggestions. At the end of this activity, teacher requested other students to applaud their friends as their appreciation for their efforts to present their understanding in front of the class. However, the lesson plan showed that students' asked to do a role-play but in its implementation at the second and third meetings this activity were not carried out because most of the time allocated on associating activities.

\section{Communicating}

At the first meeting, students presented their parents' jobs and also provided a brief description of what they do in their work. In this activity students are asked to discuss the questions and answers it by completing the 
words in each column on the table on page 129 with their classmates. In general, teacher has implemented it by involving students to discuss in groups. If in the discussion they still facing the problems, teacher immediately will help them. This activity carried out in groups so that they can learn to create simple dialogues based on examples on the textbooks and also encourage them to communicate with their partner so they will be more confident in conveying the results they had discussed.

In this activity students are asked to convey the results of their understanding both oral and written. The activities that can be done include: demonstrating, writing, presenting, editing friends' work, publishing works on wall magazines, student bulletins and others. Teachers are expected to be able to apply this approach in learning and also help build students' skills to communicate in English. The use of a scientific learning approach can help students to applying the four skills (listening, speaking, reading and writing) in an integrated manner and improving the ability of students to communicate with their peers, (Zaim, 2017)

In the pre-liminary learning activities, students are invited to receive learning that can help them to improve their concentration and motivation in learning (Hamalik, 2014; Mulyasa, 2016). The result showed not all students welcomed it enthusiastically because the students only answered improperly and only followed the answers from other friends. Facing this obstacle, the teacher tries to encourage students by asking them about the last meeting materials so they can focus on the teaching activity. In this activity, the teacher also tries to involve the scientific activity even though in its implementation each teacher has a different way of starting a lesson.

On the other side, the core activity is an important activity process because it involves all the components that will be discussed in learning. In the core activity the teacher has divided the implementation of teaching and learning activities by incorporating a scientific approach. In general, the teacher asks students to listen to the teacher's explanation about the material and read simple text related to the theme being taught. Here the teacher will start by reading a simple text then ask students to imitate it. In the core activities the teacher only acts as a facilitator who facilitates students when they experience problems or do not understand learning. Students are invited to be able to complete and understand learning themes with their creativity and understanding and confirm this to the teacher. Although in practice not all aspects of the scientific approach can be implemented by teachers due to technical constraints in the field. This is also emphasized by Zaim, (2017) that there are steps in a scientific approach that are difficult for teachers to carry out in learning.

The teacher tried to follow the lesson plan which contain the scientific activity by developing the activity according to the conditions and learning 
situations in the classroom. The teacher made improvements to the learning objectives, performs specific classification and adds activities that students must obtain. Moreover, the teacher also prepared additional learning resources that are taken from the internet as the additional information for students.

In the discussion activity, it can be carried out in two directions, either from the teacher or students. In this activity the teacher asked for various information, purposes and functions in the dialogue or text discussed. The teacher tried to explore the students understanding related to the material being taught. The concepts and students' understanding are explored so that students can be prepared to enter the next learning materials. Moreover, students have highly participation in the learning activity. Students are asked to play a role, discuss, ask questions, help explain simple material to other friends in the group, and also draw conclusions based on the material that has been taught. The teacher only acts as a facilitator who facilitates students when they encounter obstacles in the learning activities.

At the end of the learning activity in general the teacher has ended it well by asking questions related to what they have learned; whether students already understand or not with the material given and also provide additional assignments to do at home. This is also emphasized by Mulyasa (2014) that in the final activity the assignment given is a follow-up to the core learning activities that are carried out at that time. However, due to the time spending on the core activities, sometimes at the end of this lesson the teacher has not in giving feedback related to learning at that time.

In the learning process activities using scientific approach, the teacher feels that what is being done has not yet fulfilled all the steps of scientific learning activities which is contained in the lesson plan. The teacher has to repeat the explanation several times because the students have not get a good understanding and the class situation is noisy. The total teaching allocation at about 80 minutes per meeting was spent more on the pre-liminary activity and core learning activities because in this learning process the teacher must observe all the processes carried out by students.

During the learning process the teacher tried to make scientific activities run well and efficiently by asking students to sit in groups. Doing teaching activity in group help teacher easily to control the class and make the students can collaborate with others to solve the assignment or material given. The formation of this group also makes learning more efficient in terms of time. Because of the time limitations the teacher asked students to prepare a vocabulary book where they can write down difficult words find on the material being taught. The teacher also asks students in peer to perform role playing, this strategy is used to dare students to appear in front of their friends. 
There are some problems appear while implementing this approach. The lack of learning text books make they have to share it with their partner. The teacher sometimes has to copying the material that is not in the textbook to be given to the students. Other problems also arise in learning activity because many students do not have a dictionary so the teacher had to translating a few words from the teaching material to them. This is also a problem expressed by the researchs of Wong, 2008; Byrne et al., 2013; Intansari, 2013; Febriana, et al, 2018. Therefore, the readiness from all elements regarding to this matter needs to be considerate by the government to support the implementation of the 2013 curriculum properly.

\section{CONCLUSION}

Competency-based curriculum is related to how students can have independence and expertise in various elements of knowledge, attitudes and professionalism so that they can use their learning experiences as in the real world (Nikolov et al., 2014). On the other hand, the competency-based curriculum also provides opportunities for teachers to identify students potentiality and to cultivate this potential through existing learning to improve the individual quality of the students themselves, (Ji, Lili \& Kabita, 2017; Curry \& Docherty, 2017). The competencies that students are expected to have are basic competencies that have a holistic and integrated character, including: knowledge, abilities, attitudes, values and emotions (Barbero Andrés, 2012)

Research on competency-based curricula has been widely conducted. Some of these studies show that: the competency-based curriculum cannot be implemented effectively, therefore the curriculum, instruction and assessment cannot be correlated with one another (Wong, 2008) and teachers have difficulty developing the desired competencies due to various obstacles encountered, among others: large classes, limited learning time and the inability of teachers to implement this curriculum properly (Byrne et al., 2013).

It can be conveyed that in general, teacher has carried out learning activities using scientific approach. Teacher as the part of this curriculum implementation has perform their big effort in order to apply scientific approach ideally but in fact there are lots of problem face by them in implementing it. So, the support from the Government, Minister of Education and Culture, parents and all the pedagogical environment is really needed to help the teacher creates a better teaching and learning activity through the implementation of scientific approach. 


\section{REFERENCES}

Azizah, S. E. A. \& I. A. (2015). Implementasi Pendekatan Scientific Dalam Pengajaran Bahasa Inggris Kurikulum 2013 di SMPN 1 Pamekasan. Okara, 2(November 2015), 296-315. https://doi.org/10.19105/ojbs.v9i2.688

Barbero Andrés, J. (2012). CLIL: perspectives from a competency-based approach in the spanish context. Estilos de Aprendiraje: Investigaciones $y$ Experiencias: [V Congreso Mundial de Estilos de Aprendizaje], Santander, 27,

$\begin{array}{lllllll}28 & y & 29 & \text { de } & \text { Junio }\end{array}$
http://dialnet.unirioja.es/descarga/articulo/4637073.pdf\%5Cnhttp:/ / dialnet.unirioja.es/servlet/extart?codigo $=4637073$

Byrne, J., Downey, C., \& Souza, A. (2013). Teaching and learning in a competence-based curriculum: The case of four secondary schools in England. Curriculum Journal, 24(3), 351-368. https://doi.org/10.1080/09585176.2012.731008

Curry, L., \& Docherty, M. (2017). Implementing Competency-Based Education. Collected Essays on Learning and Teaching, 10, 61-74. https://doi.org/10.22329/celt.v10i0.4716

Febriana, M., Nurkamto, J., Rochsantiningsih, D., \& Muhtia, A. (2018). Teaching in Rural Indonesian Schools: Teachers' Challenges. International Journal of Language Teaching and Education, 2(2), 87-96.

Hamalik, O. (2014). Kurikulum dan Pembelajaran, (Cet. Keempatbelas). Bumi Aksara.

Intansari, R. (2013). Teachers' Strategy in Implementing English Curriculum in A Junior High School in Indonesia. Indonesian Journal of Applied Linguistics, 2(2), 226-235. https://doi.org/10.17509/ijal.v2i2.167

Ji, Lili \& Kabita, D. N. (2017). The Why, what and how of competency-based curriculum reforms: the Kenyan experience; Current and critical issues in curriculum, learning and assessment; Vol.:11; 2017. http://unesdoc.unesco.org/images/0025/002504/250431e.pdf

Jusnita, N., \& Ismail, A. (2018). Implementasi Kurikulum 2013 Dalam Pembelajaran Bahasa Inggris Di SMP Kota Ternate. Edukasi, 16(1), 110. https://doi.org/10.33387/j.edu.v16i1.616

Kemendikbud. (2016). Permendikbud No. 21 Tabun 2016 - Standar Isi Pendidikan Dasar dan Menengah.

Kementerian Pendidikan dan Kebudayaan. (2014). Implementasi Kurikulum 2013 Konsep dan Penerapan. Kementrian Pendidikan Dan Kebudayaan, 1162. 
Lee, Keunho, \& Ibe. (2014). Competency-based curriculum and curriculum autonomy in the Republic of Korea; IBE working papers on curriculum issues; Vol.:12; 2014. UNESCO IBE, April, 1-12.

Madya, S. (2007). Searching for an Appropriate Efl Curriculum Design for the Indonesian Pluralistic Society. TEFLIN Journal, 18(2), 196-221. https://doi.org/10.15639/teflinjournal.v18i2/196-221

Miles, Mattew B, Huberman, A. Michael, \& Saldana, J. (2014). Qualitative Data Analysis. A Methods Sourcebook (Third Edit). SAGE Publication.

Moleong, L. . (2017). Metodologi Penelitian Kualitatif. PT. Remaja Rosdakarya.

Mulyasa, H. . (2014). Implementasi Kurikulum Tingkat Satuan Pendidikan ( Kemandirian Guru dan Kepala Sekolah) (Cet. Kelima)e. Bumi Aksara.

Mulyasa, H. . (2016). Pengembangan dan implementasi kurikulum 2013. (Cet. Kedelapan). Bumi Aksara.

Nikolov, R., Shoikova, E., \& Kovatcheva, E. (2014). Competence Based Framework. For Curriculum Development Competence Based Framework For Curriculum Development Pictet: Eqf-Based Professional Ict Training For Russia And Kazakbstan. Za bukvite, O'pismeneh. https://unesco.unibit.bg/sites/default/files/CBFramework_TEMPUS -PICTET_Nikolov_Shoikova_Kovatcheva.pdf

Menteri Pendidikan dan Kebudayaan Republik Indonesia, (2013).

Peraturan Menteri Pendidikan dan Kebudayaan Republik Indonesia Nomor 22 Tahun 2016 tentang Standar Proses Pendidikan Dasar dan Menengah, (2016).

Sriwahyuni, E. (2015). Pembelajaran Bahasa Inggris Berdasarkan Pendekatan Saintifik Kurikulum 2013 Di Kelas Vii Mts Negeri Padang Luar. AlFikrah: Jurnal Manajemen Pendidikan, 3(2), 187. https://doi.org/10.31958/jaf.v3i2.402

Sundayana, W. (2015). Readiness and Competence of Senior High School English Teachers to Implement Curriculum 2013. Indonesian Journal of Applied Linguistics, 5(1), 28-35. https://doi.org/10.17509/ijal.v5i1.828

Wong, R. M. H. (2008). Competency-based English Teaching and Learning: Investigating Pre-Service Teachers of Chinese's Learning Experience. Porta Linguarum, 9, 179-198.

Zaim, M. (2017). Implementing Scientific Approach to Teach English at Senior High School in Indonesia. Asian Social Science, 13(2), 33. https://doi.org/10.5539/ass.v13n2p33 